\title{
Global food supply: land use efficiency of livestock systems
}

\author{
Hannah H. E. van Zanten ${ }^{1,2} \cdot$ Herman Mollenhorst $^{1} \cdot$ Cindy W. Klootwijk $^{1}$ • \\ Corina E. van Middelaar ${ }^{1}$ - Imke J. M. de Boer ${ }^{1}$
}

Received: 29 January 2015 / Accepted: 21 July 2015 /Published online: 12 August 2015

(C) The Author(s) 2015. This article is published with open access at Springerlink.com

\begin{abstract}
Purpose Livestock already use most global agricultural land, whereas the demand for animal-source food (ASF) is expected to increase. To address the contribution of livestock to global food supply, we need a measure for land use efficiency of livestock systems.

Methods Existing measures capture different aspects of the debate about land use efficiency of livestock systems, such as plant productivity and the efficiency of converting feed, especially human-inedible feed, into animal products. So far, the suitability of land for cultivation of food crops has not been accounted for. Our land use ratio (LUR) includes all above-mentioned aspects and yields a realistic insight into land use efficiency of livestock systems. LUR is defined as the maximum amount of human-digestible protein (HDP) derived from food crops on all land used to cultivate feed required to produce $1 \mathrm{~kg}$ ASF over the amount of HDP in that $1 \mathrm{~kg}$ ASF. We illustrated our concept for three case systems.

Results and discussion The LUR for the case of laying hens equaled 2.08, implying that land required to produce $1 \mathrm{~kg}$ HDP from laying hens could directly yield $2.08 \mathrm{~kg}$ HDP from human food crops. For dairy cows, the LUR was 2.10 when kept on sandy soils and 0.67 when kept on peat soils. The
\end{abstract}

Responsible editor: Greg Thoma

Hannah H. E. van Zanten

hannah.vanzanten@wur.nl

1 Animal Production Systems group, Wageningen University, P.O. Box 338, $6700 \mathrm{AH}$ Wageningen, the Netherlands

2 Wageningen UR Livestock Research, Wageningen University, P.O. Box 338, $6700 \mathrm{AH}$ Wageningen, the Netherlands
LUR for dairy cows on peat soils was lower compared to cows on sandy soils because land used to grow grass and grass silage for cows on peats was unsuitable for direct production of food crops. A LUR $<1.0$ is considered efficient in terms of global food supply and implies that animals produce more HDP per square metre than crops.

Conclusions Values $<1.0$ demonstrate that livestock produce HDP more efficiently than crops. Such livestock systems (with a LUR $<1.0$ ), therefore, do have a role in future food supply and therefore contribute to food security. Our LUR offers identification of livestock production systems that contribute to global food supply, i.e. systems that value land with low opportunity costs for arable production and/or byproducts from crop cultivation or the food or energy industry.

Keywords Feed efficiency · Food security $\cdot$ Human-inedible feed $\cdot$ Land scarcity $\cdot$ Life cycle assessment $\cdot$ Livestock

\section{Introduction}

A growing and wealthier human population implies an increase in demand for their needs, such as housing, infrastructure, energy and food, especially animal-source food (ASF). The current livestock sector already uses about $70 \%$ of global agricultural land (FAO 2009). The expected increase in demand for ASF, therefore, will further intensify global pressure on land. An increased pressure on land amplifies the risk of converting forests, wetlands or natural grasslands into agricultural land, resulting in emission of greenhouse gases and the loss of biodiversity and other important ecosystem services (Godfray et al. 2010; Foley et al. 2011). To limit land conversion, it is essential to e.g. improve land use efficiency of livestock systems. 
It is generally acknowledged that increasing yields on existing land is key to improve land use efficiency in agriculture (Godfray et al. 2010; Tilman et al. 2011). Similarly, land use efficiency of livestock systems will improve with increasing yields of grazed pastures and feed crops per hectare. Land use efficiency of livestock systems, furthermore, can improve by increasing feed efficiency, i.e. the efficiency of converting feed into ASF (De Vries and De Boer 2010). Besides increasing crop or animal productivity, land use efficiency of livestock systems improves also by increasing the efficiency along the entire food chain, from "field-to-fork", implying a reduction in, for example, grazing losses, losses while storing feed crops, or losses while consuming ASF.

It is increasingly recognized that, to achieve future food security, we might better not use highly productive croplands to produce feed for livestock. No matter how efficiently produced, direct consumption of cereals by humans is ecologically more efficient than consumption of ASF produced by animals fed with these cereals (Godfray et al. 2010; Foley et al. 2011). Improving land use efficiency of livestock systems, therefore, also implies feeding livestock mainly by-products from arable production or the food processing industry, that are not edible for humans; or grazing of livestock on "marginal land", i.e. land with low opportunity costs for arable production (Garnett 2009; Eisler et al. 2014).

All above-described aspects are essential to improve land use efficiency of livestock systems to increase food supply and therefore contribute to food security. The urgent question remains, however, how land efficient are various livestock systems in terms of food supply? In this paper, we describe a novel method to calculate land use efficiency of livestock systems, which enables identification and improvement of systems that do have a role in future food supply. To illustrate our concept, we computed our novel method for three case systems in the Netherlands: production of ASF (eggs and meat) from laying hens and production of ASF from dairy cows (milk and meat from the dairy farm) on peat soils and on sandy soils.

To demonstrate the importance of our novel concept, we compared our findings with existing measures for land use efficiency. We, therefore, first describe in more detail how land use efficiency of livestock systems has developed and was measured to date.

\section{Methods}

\subsection{Current drivers and existing measures of land use efficiency of livestock systems}

In the past, improving land use efficiency of livestock systems was mainly driven by economic incentives and was directed at increasing productivity per hectare of land. Consequently, crop and animal productivity per hectare has increased enormously. For most cereal crops in the world, yields have increased almost linearly since 1960. Average US maize production, for example, increased $114 \mathrm{~kg}$ per hectare per year between 1960 and 2011 (Grassini et al. 2013). Similarly, feed efficiency of livestock has improved continuously. The feed conversion ratio (FCR) of broilers (i.e. $\mathrm{kg}$ feed used per $\mathrm{kg}$ of final body weight), for example, was estimated to reduce by $0.02 \mathrm{~kg}$ feed $/ \mathrm{kg}$ broiler meat per year between 1960 and 2013 (Neeteson-van Nieuwenhoven et al. 2013).

The enduring focus on reducing FCR in livestock, however, also led to large amounts of human-edible plant products, like cereal grains, in livestock diets. Annually, about 1 billion tons of cereal grains are fed to livestock (Eisler et al. 2014). Direct consumption of these cereals by humans is more efficient in terms of global land use than consumption of products derived from livestock fed with these cereals because energy is lost during conversion from plant to animal product (Goodland 1997). In a situation where land availability is no longer abundant, i.e. feeding a growing world population with a given amount of land, improving FCR in livestock might not necessarily imply improving global land use efficiency. To determine the role of livestock in terms of global food supply, we are in need of a measure that accounts for the competition for land between livestock and human.

One way to measure this competition for land is to compute human-edible protein and energy conversion ratios (Wilkinson 2011; Dijkstra et al. 2013). These conversion ratios represent the amount of energy or protein in animal feed that is potentially edible for humans over the amount of energy or protein in that animal product that is edible for humans. Ratios above 1, such as for UK broilers, laying hens, pigs and some cattle, are unsustainable because animals produce less edible protein and/ or energy than they consume (Wilkinson 2011). A ratio below 1, such as for UK milk production (Wilkinson 2011), does not immediately imply efficient land use in terms of global food supply because these conversion ratios do not yet include the fact that, for example, grass fed to dairy cows can be produced on land suitable for the cultivation of human food crops, or in other words, they do not include the opportunity costs of land for human food production.

The above-described conversion ratios originally focused on the efficiency of animals to convert feed or specifically human-inedible feed into animal products. Besides improving crop yield per hectare or the feed efficiency of animals, it is increasingly recognized that land use efficiency by livestock should be examined along the entire livestock supply chain. Over the last years, several studies were published that assessed land use by livestock along the entire supply chain (De Vries and De Boer 2010), generally using life cycle assessment (LCA). At present, LCA is an internationally acknowledged method to quantify use of natural resources, 
such as land or fossil energy, during the entire life cycle of a product (Guinée et al. 2002). An LCA quantifies the land needed to produce $1 \mathrm{~kg}$ ASF and implicitly combines information about crop productivity (i.e. crop yield per ha) and animal productivity (i.e. feed efficiency along the chain, including breeding, rearing and producing animals). Current LCA results show that production and utilization of feed are the dominant factors determining land use efficiency of livestock systems. Several LCA studies determined the land use efficiency of contrasting livestock products. They concluded that production of $1 \mathrm{~kg}$ of beef protein uses most land, followed by production of $1 \mathrm{~kg}$ of pork, chicken, egg or milk protein (De Vries and De Boer 2010; Eshel et al. 2014). Interpretation of current LCA results, however, is hindered because results do not include differences in consumption of human-edible products by livestock or differences in suitability of land used for feed production to directly cultivate food crops, or in other words, they do not account for the competition between humans and animals for land. Grass-fed beef cattle, for example, generally consume less human-edible products than pigs or poultry and can value grassland that is less suitable for production of food crops.

Several LCA studies did propose a way to account for differences in quality of land (Ridoutt et al. 2012; Borucke et al. 2013). Net primary productivity of potential biomass $\left(\mathrm{NPP}_{0}, \mathrm{~g} \mathrm{C} \mathrm{m}^{-2}\right.$ year $\left.^{-1}\right)$, for example, was used as proxy to account for differences in land quality (Ridoutt et al. 2012). According to this approach, land use of various agricultural products is assessed by multiplying each spatially differentiated area of land use by its net primary productivity divided by global average net primary productivity. Using net primary productivity as a proxy for land quality, however, does not yet include the fact that, for example, feed crops fed to dairy can be produced on land less suitable for the cultivation of human food crops or, in other words, that livestock can produce human-edible protein from land with low opportunity costs for human food production.

Existing measures for efficiency of land use for livestock systems capture different aspects of the debate. The FCR focuses on the efficiency of animals to convert feed into animal products; protein and energy conversion ratios focus on the efficiency of animals to convert human-inedible feed into animal products; and an LCA focusses on the total amount of land required to produce $1 \mathrm{~kg} \mathrm{ASF}$ and combines plant and animal productivity. None of these measures includes the opportunity costs of land for crop production. To address the contribution of livestock to increase food supply and therefore contribute to food security, we are in need of a measure for land use efficiency that accounts for plant productivity, efficiency of converting especially human-inedible feed into animal product and the opportunity cost of land for crop cultivation and has a life cycle perspective.

\subsection{Novel measure for land use efficiency of livestock systems}

Our measure of land use efficiency of livestock systems includes all above-mentioned aspects to determine the role of livestock in terms of food supply and is defined as the following land use ratio (LUR):

$\mathrm{LUR}=\frac{\sum_{i=1}^{n} \sum_{j=1}^{m}\left(\mathrm{LO}_{i j} \times \mathrm{HDP} \mathrm{m} \mathrm{m}_{j}^{-2}\right)}{\text { HDP of one } \mathrm{kg} \mathrm{ASF}}$

where $\mathrm{LO}_{i j}$ is the land area occupied for a year $\left(\mathrm{m}^{2}\right.$ year) to cultivate the amount of feed ingredient $i(i=1, n)$ in country $j(j=1, m)$ that is needed to produce $1 \mathrm{~kg}$ ASF, including breeding and rearing of young stock, and $\mathrm{HDP}_{j}$ is the maximum amount of human-digestible protein (HDP) that can be produced per $\mathrm{m}^{2}$ year by direct cultivation of food crops in country $j$. The denominator contains the amount of HDP of $1 \mathrm{~kg} \mathrm{ASF}$.

To compute the LUR of $1 \mathrm{~kg}$ ASF from a specific livestock system, four steps are required. First, you quantify the land area occupied $\left(\mathrm{LO}_{i j}\right)$ to cultivate the amount of each feed ingredient $(i=1, n)$ in the different countries of origin $(j=1, m)$ that are needed to produce $1 \mathrm{~kg}$ ASF. Second, you assess the suitability of each land area occupied to directly grow human food crops, using the crop suitability index (IIASA and FAO 2012). Third, for each area of land suitable for direct cultivation of food crops $\left(\mathrm{LO}_{i j}\right)$, you determine the maximum $\mathrm{HDP}_{j}$ from cultivation of food crops by combining information about crop yield per hectare for each suitable crop, with its protein content and human digestibility. The amount of HDP that can be produced on all land required for feed production is summed and used as numerator. Fourth, you assess the amount of HDP in $1 \mathrm{~kg} \mathrm{ASF}$, which is the denominator.

LUR, therefore, represents the maximum amount of HDP derived from food crops on all land used to cultivate feed required to produce $1 \mathrm{~kg}$ ASF over the amount of HDP in that $1 \mathrm{~kg}$ ASF. A ratio above 1 implies that the land required to produce this kilogramme ASF would yield more HDP if used directly to cultivate human food crops, whereas a ratio below 1 implies that livestock production is the best way to produce HDP from that land.

The four steps of our concept will be further explained by computing the three case studies described below.

\subsection{Computation of land use efficiency of case systems}

To illustrate our concept, we computed our novel method for three case systems in the Netherlands: production of ASF from laying hens (eggs and meat) and production of ASF from dairy cows (milk and meat from the dairy farm) on peat soils and on sandy soils. We distinguished dairy farming on peat soils and sandy soils because of their difference in suitability 
to cultivate food crops. Furthermore, we compared our novel method with currently available methods; FCR, the protein and energy conversion ratio and $\mathrm{LO}_{\mathrm{LCA}}$, for protein and energy. The calculations for our novel method and the current methods are based on the same data.

\subsubsection{Land use ratio}

1. Quantify land area occupied to cultivate feed ingredients. We analysed the most common laying hen system in the Netherlands, i.e. a multi-tier barn system with brown hens. Our production system included the rearing and laying hen phase, whereas production of day-old hens and parent stock were excluded. Feed intake of rearing and laying hens was calculated based on technical data of KWIN-V 2013 (Table 1).

Rearing hens were assumed to consume only one type of concentrate feed. The composition of this concentrate feed was based on Dekker et al. (2011) and is reported in Table 2. Laying hens were fed a starter feed during the first 23 weeks, followed by a regular feed (personal communication, L. Start, Schothorst Feed Research, Lelystad, the Netherlands). The composition of starter and regular feed for laying hens was based on recent advices for commercial feed (Gijsberts 2013a, $\mathrm{b}, \mathrm{c}, \mathrm{d})$. The weighted average of the starter and regular feed of laying hens is presented in Table 2.

For each feed ingredient, the country of origin and yields per hectare were based on a database called 'feedprint', feedprint (based on currently available literature) provides information on the environmental impact of feed ingredients used in the Netherlands (Vellinga et al. 2013). Given the exact amount of feed ingredients consumed, and their yields per hectare, we quantified the area occupied to cultivate all feed ingredients. In case of a multiple-output situation, land use was allocated to the various outputs based on their relative economic value (i.e. economic allocation). Crop residues, such as citrus and beet pulp, maize gluten meal and straw,

Table 1 Technical and economic data for Dutch egg production in a multi-tier barn system (KWIN-V 2013)

\begin{tabular}{lc}
\hline Technical parameter & Value \\
\hline Feed intake of hen in rearing phase (kg/rearing hen/round) & 6 \\
Mortality rate between 17 and 20 weeks $(\%)$ & 0.3 \\
Mortality rate from 20 weeks onwards (\%) & 10 \\
Feed intake of hens from 17 weeks onwards (kg/hen/round) & 48.8 \\
Egg production ( $\mathrm{kg} /$ hen/round) & 21.2 \\
Slaughter weight of laying hens ( $\mathrm{kg} / \mathrm{hen})$ & 1.8 \\
Egg price $(€ / \mathrm{kg})$ & 0.951 \\
Slaughter price $(€ / \mathrm{kg})$ & 0.18 \\
\hline
\end{tabular}

Table 2 Composition of concentrate feed for rearing and laying hens (g/kg) (based on Dekker et al. 2011 and Gijsberts 2013a, b, c, d)

\begin{tabular}{lcc}
\hline Feed ingredient & Rearing hen & Laying hen \\
\hline Maize & 411 & 539 \\
Wheat & 399 & 83 \\
Soybean expeller & 115 & \\
Soybean meal $(0-45 \mathrm{CF} ;>480 \mathrm{CP})^{\mathrm{a}}$ & & 170 \\
$\begin{array}{l}\text { Sunflower seed expelled with hulls } \\
\text { Distillers dried grains and solubles (DDGS) }\end{array}$ & 75 & 79 \\
Fats/oils vegetable & 21 \\
Amino acids, minerals, enzymes and chalk ${ }^{\mathrm{b}}$ & & 108 \\
\hline${ }^{\mathrm{a} C F}$ crude fibre, $C P$ crude protein $(\mathrm{g} / \mathrm{kg})$ & \\
${ }^{\mathrm{b}}$ Components without associated agricultural land use &
\end{tabular}

were assumed to have an economic value of zero (Vellinga et al. 2013).

For dairy farming, we selected dairy production systems in the Netherlands with $>90 \%$ sandy soils or $>90 \%$ peat soils. Technical data required to determine all land used to cultivate feed required to produce $1 \mathrm{~kg}$ ASF from this system were based on the Dutch Farm Accountancy Data Network (FADN 2014) and are shown in Tables 3 and 4. Feed intake of the whole dairy herd, including young stock, was based on average technical data between 2010 and 2012 (Table 3).

Table 3 shows average technical and economic data for Dutch dairy production system on peat or sand. To quantify the land occupied for the cultivation of a feed ingredient, we corrected these data for feeding and conservation losses (Table 4). Feeding and conservation losses of grazing animals were assumed negligible (RIVM 2013). Furthermore, we assumed all maize silage to be purchased because no data were available to exactly determine the production of on-farm maize silage.

Purchased concentrates were assumed to be $70.5 \%$ protein-rich (19.6\% crude protein) and $29.5 \%$ very proteinrich (30.4\% crude protein) for dairy cows on sandy soils, and $16.2 \%$ standard (14.1\% crude protein) and $83.8 \%$ proteinrich for dairy cows on peat soils (Table 5). Table 5 shows the composition of each type of concentrate. The amount of both concentrate types purchased was computed by combining information from the total amount of crude protein and energy in purchased concentrates (Table 3) and the crude protein-toenergy ratio of both types of concentrates (Vellinga et al. 2013). Given the amount of concentrates consumed, and their related average yields per hectare, we quantified the area occupied to cultivate all feed ingredients (Vellinga et al. 2013).

Similarly, the amount of purchased wet by-products, brewers grain and sugar beet pulp was computed by combining information from the total amount of crude protein and energy in purchased wet by-products (Table 3 ) and the crude protein-to-energy ratio of both products. Given the amount of 
Table 3 Average technical and economic data for Dutch dairy production system on peat $(n=23)$ or sand $(n=100)$ (Dutch Farm Accountancy Data Network 2014)

\begin{tabular}{|c|c|c|}
\hline Technical parameter & Dairy peat & Dairy sand \\
\hline Number of milking cows & 90 & 94 \\
\hline Number of young stock $<1$ year & 27 & 35 \\
\hline Number of young stock $>1$ year & 29 & 35 \\
\hline Milk production per cow (kg/year) & 6353 & 8114 \\
\hline Milk production per hectare (kg/year) & 10,623 & 15,118 \\
\hline Total milk production per farm (kg/year) & 571,912 & 761,795 \\
\hline Fat in milk $(\%)$ & 4.38 & 4.41 \\
\hline Protein in milk (\%) & 3.51 & 3.54 \\
\hline Total sold meat (kg live weight/year) & 12,060 & 17,368 \\
\hline Economic allocation milk (\%) & 85 & 87 \\
\hline \multicolumn{3}{|l|}{ Feed intake parameters } \\
\hline Grass intake via grazing $\left(\mathrm{GJ} \mathrm{NE}_{\mathrm{L}}^{\mathrm{a}}\right)$ & 630.7 & 321.9 \\
\hline Grass intake via silage $\left(\mathrm{GJ} \mathrm{NE}_{\mathrm{L}}\right)$ & 2043.3 & 1704.1 \\
\hline Maize silage ${ }^{b}\left(G J E_{L}\right)$ & 540.5 & 1764.6 \\
\hline Concentrate feed (GJ NE $\left.E_{L}\right)$ & 1049.3 & 1187.7 \\
\hline Wet by-products $\left(\mathrm{GJ} \mathrm{NE}_{\mathrm{L}}\right)$ & 328.9 & 206.4 \\
\hline Milk products for young stock $\left(\mathrm{GJ} \mathrm{NE}_{\mathrm{L}}\right.$ ) & 18.1 & 20.5 \\
\hline Concentrate feed total $\mathrm{N}(\mathrm{kg})$ & 4664 & 6436 \\
\hline Wet by-products total N (kg) & 826 & 953 \\
\hline \multicolumn{3}{|l|}{ Crop yields } \\
\hline Grass yield (GJ NE $\left.\mathrm{L}_{\mathrm{L}} / \mathrm{ha}\right)$ & 67.9 & 70.2 \\
\hline Grass yield (kg DM/ha) & 9157 & 9544 \\
\hline Grass yield (kg N/ha) & 255 & 253 \\
\hline
\end{tabular}

${ }^{\mathrm{a}} N E_{L}$ Net energy for lactation

b Including a small amount of feed reported as 'other' (27.9 GJ NE $\mathrm{L}_{\mathrm{L}}$ for dairy peat; $75.8 \mathrm{GJ} \mathrm{NE}_{\mathrm{L}}$ for dairy scand)

feed ingredients consumed, and their yields per hectare, we quantified the area occupied to cultivate all feed ingredients. For on-farm feed production, yields per hectare were obtained from the Dutch Farm Accountancy Data Network (FADN 2014; Table 3). For crop production outside the farm, country

Table 4 Feeding and conservation losses (in \%) for roughages and wet by-products (RIVM 2013)

\begin{tabular}{lllll}
\hline & Feeding & \multicolumn{3}{c}{ Conservation losses } \\
\cline { 3 - 5 } & Losses & $\mathrm{DM}$ & $\mathrm{NE}_{\mathrm{L}}{ }^{\mathrm{a}}$ & $\mathrm{N}$ \\
\hline Grass silage & 5 & 10 & 15 & 3 \\
Maize silage & 5 & $-{ }^{\mathrm{b}}$ & - & - \\
Concentrates/milk products (\%) & 2 & 0 & 0 & 0 \\
Wet by-products (\%) & 2 & - & 6 & - \\
\hline
\end{tabular}

${ }^{\text {a }} N E_{L}$ net energy for lactation

${ }^{\mathrm{b}}$ Not used in calculations, as nutritional value of purchased products was derived from feedprint
Table 5 Composition ( $\mathrm{g} / \mathrm{kg}$ ) (Vellinga et al. 2013) of three types of concentrate feed for dairy cattle (standard, protein-rich (Rich) and extra protein-rich (Extra)) (Vellinga et al. 2013)

\begin{tabular}{lrrr}
\hline Feed ingredient & Standard & Rich & Extra \\
\hline Citrus pulp dried & 250 & 156 & 65 \\
Coconut expeller CFAT $>100^{\mathrm{a}}$ & 100 & 100 & 100 \\
Maize gluten feed CP 200-230 $^{\mathrm{b}}$ & 185 & 370 & \\
Milk powder whole & 8 & 8 & 8 \\
Palm kernel expeller CF 0-180 & 150 & 150 & 150 \\
Rapeseed expeller & & 50 & \\
Rapeseed extruded CP 0-380 & & & 126 \\
Soybean hulls CF 320-360 & 150 & & \\
Soybean meal CF 45-70; CP 0-450 & & & 320 \\
Soybean meal Mervobest & & 76 & 140 \\
Sugarcane molasses SUG $>475^{\text {d }}$ & 30 & 30 & 30 \\
Sunflower seed expelled with hulls & & & \\
Triticale & 13 & & \\
Vinasse sugarbeet CP 0-250 & 40 & 40 & 40 \\
Wheat middlings & 73 & 8 & \\
Others, like salt, chalk & & 14 & 22 \\
\hline
\end{tabular}

${ }^{\mathrm{a}} \mathrm{CFAT}=$ crude fat $(\mathrm{g} / \mathrm{kg})$

${ }^{\mathrm{b}} \mathrm{CP}=$ crude protein $(\mathrm{g} / \mathrm{kg})$

${ }^{\mathrm{c}} \mathrm{CF}=$ crude fibre $(\mathrm{g} / \mathrm{kg})$

${ }^{\mathrm{d}} \mathrm{SUG}=$ sugar $(\mathrm{g} / \mathrm{kg})$

${ }^{\mathrm{e}}$ Components without associated agricultural land use

of origin and yields per hectare were obtained from feedprint (Vellinga et al. 2013).

2. Determine the suitability of land to directly cultivate human food crops. For each area of land identified for feed production, we determined its suitability to directly grow food crops. On each area of land suitable to grow food crops, different crops can be cultivated. We focused on the five major food crops as the yield of those crops are high and therefore the amount of protein per hectare is also high. The suitability for the five major food crops, i.e. wheat (wetland and indica dry land), maize, potatoes (white and sweet) and soybeans, at a specific location was assessed based on the Global Agro-Ecological Zones (GAEZ) database (IIASA and FAO 2012). This database classifies crop suitability in eight groups (varying from very high to not suitable), by quantifying to what extent soil (e.g. pH, soil water holding capacity) and climatic conditions (e.g. wet day frequency, sunshine, temperature) match crop requirements, under defined input and management circumstances. We assessed crop suitability for current cultivated land in a situation of high input levels, optimal water supply and baseline climate conditions (1961-1990). If the suitability of the crop was good, high, or very high (suitability index $>55$ ), the 
land was considered suitable to cultivate that specific crop.

3. Calculation of HDP production from all land suitable for crop production (numerator). Human-digestible protein production from the five selected crops was calculated from their respective yields (Table 6), multiplied by their protein content and digestibility (Table 7). For on-farm land used for grass production, crop yields per hectare were assumed to be soil specific. Peat soils were assumed unsuitable for the cultivation of any of the five major food crops, whereas sandy soils were assumed suitable for cultivation of white potatoes (i.e. $56,000 \mathrm{~kg} / \mathrm{ha}$ ) and wheat (7300 kg/ha) (KWIN-AGV 2012). For off-farm crop production, country-average yield data from FAOstat were used (Table 6), as information about exact location and, consequently, soil type were missing. Subsequently, the highest HDP for each area of land was chosen and summed across all land areas required to produce $1 \mathrm{~kg}$ of ASF. This sum of HDP was used as numerator of our land use ratio. Because animal-source food contributes not only to the protein but also to the energy demand of humans, we also computed our land use ratio from an energy perspective, implying that HDP was replaced by human-digestible energy. For human-digestible energy, values of the energy content (Table 7) were directly derived from a USDA database (United States Department of Agriculture (USDA) 2013). For chicken meat, we assumed that $56 \%$ of live weight was edible and for beef, this was $43 \%$ (De Vries and De Boer 2010).
4. Calculation of HDP of $1 \mathrm{~kg}$ of animal-source food (denominator). The amount of HDP in $1 \mathrm{~kg}$ of ASF was computed by multiplying with its protein content and its protein digestibility for humans. The amount of humandigestible energy in $1 \mathrm{~kg}$ of ASF was computed by multiplying with its energy content for humans.

\subsubsection{Assessing existing measures of land use efficiency of livestock systems}

To demonstrate our concept, we compared LUR values with existing measures of land use efficiency. To allow an accurate comparison, we computed existing measures (FCR, protein and energy conversion ratios, and $\mathrm{LO}_{\mathrm{LCA}}$ ) for each case system using the same data as we used to compute LUR.

The feed conversion ratio (FCR) was defined as the amount of DM in feed supplied to the producing animal over the kilogramme of main output of that animal $(\mathrm{kg}$ egg and $\mathrm{kg}$ fat-protein-corrected milk; CVB 2012). A higher FCR indicates a lower efficiency of converting feed into animal product and implies a lower efficiency of land use. Feed intake was already assessed in the first step of our novel approach. Feed intake data as presented in Table 3, however, were computed for the entire herd. To correct for feed intake of young stock in the computation of feed, energy and protein conversion ratios, we assumed a total intake from birth until first lactation of $31 \mathrm{GJ} \mathrm{NE}_{\mathrm{L}}$ per animal $\left(\mathrm{NE}_{\mathrm{L}}=\right.$ net energy for lactation), of which $19 \%$ consisted of concentrate feed

Table 6 Country average yields (kg/ha) of five major food crops for the year 2011 (FAOstat; http://faostat.fao.org). An empty cell implies a country was considered unsuitable to cultivate that crop (i.e. suitability index $<55$ )

\begin{tabular}{|c|c|c|c|c|c|c|c|}
\hline Country & Maize & Potatoes (sweet) & Potatoes (white) & Rice (dry) & Rice (wet) & Soybeans & Wheat \\
\hline Argentina & 6350 & 15,083 & 30,383 & & 6790 & 2605 & 3136 \\
\hline Australia & 5739 & 24,546 & 35,089 & & 9544 & 1714 & 2030 \\
\hline Belgium & & & 50,141 & & & & 8405 \\
\hline Brazil & & & 12,427 & 4896 & 4896 & 3121 & \\
\hline China & 5748 & & 16,281 & & 6686 & 1836 & \\
\hline France & 9973 & & 46,899 & & & 2947 & 6527 \\
\hline Germany & & & 45,613 & & & & 7019 \\
\hline India & 2498 & 9246 & & & 3591 & 1200 & 2989 \\
\hline Indonesia & & 12,326 & & 4980 & 4980 & 1359 & \\
\hline Malaysia & & 10,655 & & 3898 & 3898 & & \\
\hline Netherlands & & & 46,055 & & & & 7781 \\
\hline Philippines & 2740 & 4979 & & 3678 & 3678 & 1323 & \\
\hline \multicolumn{8}{|l|}{ Pakistan } \\
\hline Sudan & 1351 & 22,688 & & & 3720 & & \\
\hline Ukraine & 6445 & & & & & & 3353 \\
\hline United Kingdom & & & 41,884 & & & & 7749 \\
\hline United States & 9237 & & 44,714 & & 7921 & 2820 & 2942 \\
\hline
\end{tabular}


Table 7 Dry matter (DM), protein and human-digestible (HD) energy contents of products and human digestibility value of protein

\begin{tabular}{|c|c|c|c|c|c|}
\hline Product & Product code $\mathrm{a}^{\mathrm{a}}$ & DM (kg DM/kg product) & HD energy (MJ/kg DM) & Protein (g/kg DM) & Protein digestibility ${ }^{\mathrm{c}}(\%)$ \\
\hline Chicken egg & 01123 & 0.239 & 25.1 & 526.6 & 97 \\
\hline Chicken meat & 05001 & 0.337 & 26.5 & 544.6 & 94 \\
\hline Cow milk (sand) & 01078 & 0.123 & $27.0^{\mathrm{b}}$ & $287.8^{\mathrm{b}}$ & 95 \\
\hline Cow milk (peat) & 01078 & 0.123 & $26.9^{\mathrm{b}}$ & $285.4^{\mathrm{b}}$ & 95 \\
\hline Beef & 13002 & 0.418 & 27.9 & 418.3 & 94 \\
\hline Maize & 20014 & 0.896 & 17.0 & 105.1 & 85 \\
\hline Potatoes sweet & 11507 & 0.227 & 15.8 & 69.1 & 76 \\
\hline Potatoes white & 11354 & 0.184 & 15.7 & 91.2 & 80 \\
\hline Rice & 20052 & 0.867 & 17.3 & 75.0 & 89 \\
\hline Soybeans & 16111 & 0.915 & 20.4 & 399.0 & 78 \\
\hline Wheat & 20074 & 0.904 & 15.8 & 125.1 & 87 \\
\hline
\end{tabular}

${ }^{\text {a }}$ Product code in USDA database (USDA 2013) used to select values for DM, protein and HD energy

${ }^{\mathrm{b}}$ Case-specific data were used (see Table 3)

${ }^{\mathrm{c}}$ Source: (Gilani et al. 2005), except for potatoes (white (Kies and Fox 1972; Eppendorfer et al. 1979; Khan et al. 1992; Gahlawat and Sehgal 1998), sweet (Ravindran et al. 1995))

and milk products (CVB 2012; Dijkstra et al. 2013). All milk products as presented in Table 3 were assumed to be consumed by young stock. Average concentrate feed and roughage composition was assumed to be similar for young stock and producing cows per case system. No wet by-products were assigned to young stock. Based on those assumptions, we calculated a total feed intake of dairy cows on sandy soils of $246 \mathrm{GJ} \mathrm{NE}_{\mathrm{L}}$ grass grazing, 1300 GJ $\mathrm{NE}_{\mathrm{L}}$ grass silage, $1346 \mathrm{GJ} \mathrm{NE}_{\mathrm{L}}$ maize silage, $1001 \mathrm{GJ} \mathrm{NE}_{\mathrm{L}}$ concentrate feed and $206 \mathrm{GJ} \mathrm{NE}_{\mathrm{L}}$ wet byproducts and dairy on peat soils of $491 \mathrm{GJ} \mathrm{NE}_{\mathrm{L}}$ grass grazing, $1590 \mathrm{GJ} \mathrm{NE}_{\mathrm{L}}$ grass silage, $421 \mathrm{GJ} \mathrm{NE}_{\mathrm{L}}$ maize silage, 902 GJ NE $\mathrm{L}_{\mathrm{L}}$ concentrate feed and $329 \mathrm{GJ} \mathrm{NE}_{\mathrm{L}}$ wet by-products. The DM content of feed ingredients was taken from feedprint (Vellinga et al. 2013), whereas the DM content of on-farm grass was taken from the Dutch Farm Accountancy Data Network (FADN 2014; Table 3).

The protein conversion ratios were defined as the ratio of crude protein in animal feed directly edible for humans over kilogramme protein in eggs or milk. Similarly, the energy conversion ratio was defined as the ratio of gross energy in animal feed directly edible for humans over kilogramme gross energy in eggs or milk. A ratio above 1 implies that an animal produces less edible protein than it consumes and appears inefficient from a land-use perspective. The human-edibility of feed products was taken from the literature (Wilkinson 2011), whereas ASF was considered to be fully human-edible. We used average nutrient composition values for eggs (USDA 2013), whereas for milk, we used case-specific protein contents (Table 3).

Besides examining feed and protein conversion ratios at animal level, we also computed land use associated with feed production along the life cycle of $1 \mathrm{~kg}$ HDP from laying hens or dairy cows, including rearing of young stock. Land area occupied to cultivate feed ingredients along the chain was assessed already in the first step of our novel approach (see previous paragraph). Subsequently, it was allocated to the main product of the livestock system (i.e. egg or milk) based on economic allocation and expressed per kilogramme of human-digestible protein or per kilogramme of humandigestible energy.

\section{Results}

We first present LUR values from a 'protein' perspective, as livestock products contribute especially to the protein demand of humans (Galloway et al. 2007; De Vries and De Boer 2010) and compare those with results from existing measures of land use efficiency. Second, we present and compare results from an energy perspective.

\subsection{Results of land use ratio (protein perspective)}

The LUR for the case of laying hens equaled 2.08. A LUR of $2.08 \mathrm{implies}$ that the land required to produce $1 \mathrm{~kg}$ HDP from laying hens could directly yield $2.08 \mathrm{~kg}$ HDP from human food crops. The structure of the computation of the LUR is depicted in Fig. 1. To produce $1 \mathrm{~kg}$ of fresh egg and its associated production of $0.068 \mathrm{~kg}$ chicken meat, we needed $2.30 \mathrm{~kg}$ of feed for laying hens and $0.284 \mathrm{~kg}$ of feed for rearing hens. The main feed ingredients of laying hen feed were maize (54\%), soybean meal (17\%) and wheat ( $8 \%$ ). Half of this maize was assumed to originate from Germany and the other half from France. With a yield of $8788 \mathrm{~kg}$ per hectare, production of $0.62 \mathrm{~kg}$ maize in Germany required $0.71 \mathrm{~m}^{2}$ year. This 
Fig. 1 Illustration of our concept of land use ratio for the case system of laying hens, assuming a production of $1 \mathrm{~kg}$ of eggs and an associated production of $0.076 \mathrm{~kg}$ of chicken meat ( $D E$ Germany, $F R$ France, HDP humandigestible protein)

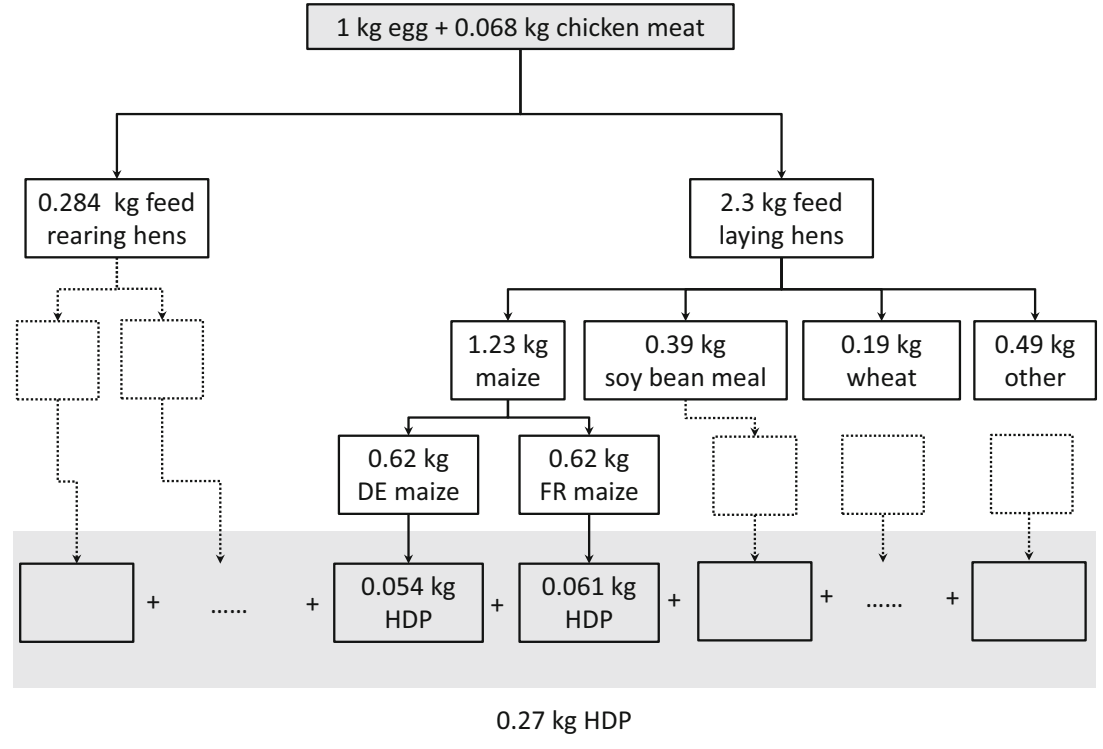

$0.71 \mathrm{~m}^{2}$ year could have been used directly to produce human food crops and could yield maximally $0.049 \mathrm{~kg}$ HDP $((7019 \mathrm{~kg}$ wheat per ha $\times 0.904 \mathrm{DM}$ per $\mathrm{kg}$ wheat $\times 125.1 \mathrm{~g}$ protein per $\mathrm{kg}$ DM wheat $\times 87 \%$ digestibility $/ 10,000) \times$ $0.71 \mathrm{~m}^{2}$ year). In total, the land used to produce $1 \mathrm{~kg}$ of eggs and associated chicken meat could have yielded directly $0.27 \mathrm{~kg}$ of HDP from human food crops. One kilogramme of eggs contains $0.12 \mathrm{~kg}$ HDP, whereas $0.07 \mathrm{~kg}$ of chicken meat contains $0.01 \mathrm{~kg}$ HDP. The LUR of eggs, therefore, equaled $0.27 / 0.13=2.08$.

Similarly, we determined a LUR of 2.10 for dairy cows on sandy soils and 0.67 for dairy cows on peat soils. The LUR of dairy cows on sand was similar to the LUR of hens, despite the fact that compared with the diet of laying hens, the diet of dairy cows contained less products that humans could consume directly (i.e. $72 \%$ of crude protein in diets of laying hens was human-edible compared to $16 \%$ for dairy cows on sand and $9 \%$ for dairy cows on peat). The land used to produce feed ingredients for laying hens and dairy cows on sandy soils, however, appeared to have about the same potential to directly produce HDP by food crops. This was not the case for dairy cows on peat soils. The land used to grow grass and grass silage for these dairy cows was assumed unsuitable for direct production of food crops, overall resulting in a LUR of 0.67 . This LUR implies that the land required to produce $1 \mathrm{~kg}$ HDP from dairy cows on peat soils could only yield $0.67 \mathrm{~kg}$ of HDP from human food crops directly. A LUR $<1.0$, therefore, is considered efficient in terms of global food supply and implies that animals produce more HDP per square metre than crops. Values $<1.0$ demonstrate that livestock do contribute to food supply and therefore food security. Our LUR offers identification of livestock production systems that use land efficiently in terms of food supply. Land-efficient livestock systems typically value land with low opportunity costs for arable production (e.g. peat soils or wet grasslands) and/or byproducts from crop cultivation or the food or energy industry (e.g. beet pulp).

\subsection{Results of existing measures of land use efficiency of livestock systems}

The FCR for producing eggs is roughly twice as high as the production of milk on peat (Fig. 2), which is in line with a UK case study (Wilkinson 2011). The FCR of dairy cows on sandy soils, however, was about $15 \%$ lower than the FCR of dairy cows on peat soils. Differences in FCR are determined mainly by differences in annual milk production per cow (Dijkstra et al. 2013). Annual milk production per cow indeed was comparable for Dutch cows on peat (i.e. $6350 \mathrm{~kg}$ ) and cows in the UK case study (Dijkstra et al. 2013) (6500 kg) but was higher for dairy cows on sand $(8114 \mathrm{~kg})$. Based on this definition of FCR, we would conclude that dairy cows are more efficient than laying hens, whereas dairy cows on sand are most efficient. Relative to eggs, however, milk has a lower DM content (i.e. milk $=12.3 \%$ DM; eggs $=23.9 \%$ DM; (18)). When we express FCR as $\mathrm{kg}$ DM in feed over $\mathrm{kg}$ DM in product, differences among FCRs between milk production and egg production are less pronounced $\left(\mathrm{FCR}_{\mathrm{egg}}=8.6\right.$; $\mathrm{FCR}_{\text {milk sand }}=6.3 ; \mathrm{FCR}_{\text {milk peat }}=7.4$ ), which is in agreement with Galloway et al. (2007).

The protein conversion ratios of laying hens are higher compared to dairy cows, which is in the range with results in literature (Wilkinson 2011; Dijkstra et al. 2013). Our laying hen system shows a protein conversion ratios of about 2 . In terms of global food supply, therefore, the existing way of egg production is not land efficient. A target ratio below 1 may be possible by replacing, for example, cereals or soybean meal (both have a high proportion of edible protein) by waste-fed 
Fig. 2 Feed conversion ratios $(F C R)$ in $\mathrm{kg} \mathrm{dm} / \mathrm{kg}$ product (i.e. eggs or milk), protein conversion ratios $(P C R)$ in $\mathrm{kg}$ human-edible protein $/ \mathrm{kg}$ human-edible product, life cycle assessments of land occupation $(L O)$ in $10 \mathrm{~m}^{2}$ year $/ \mathrm{kg}$ human-digestible protein product and our newly developed land use ratio $(L U R)$ in $\mathrm{kg}$ humandigestible protein in crops/ human-digestible protein in animal source food. All methods are applied for three case systems in the Netherlands, laying hens (black), dairy cows on sand (grey) and dairy cows on peat (white)

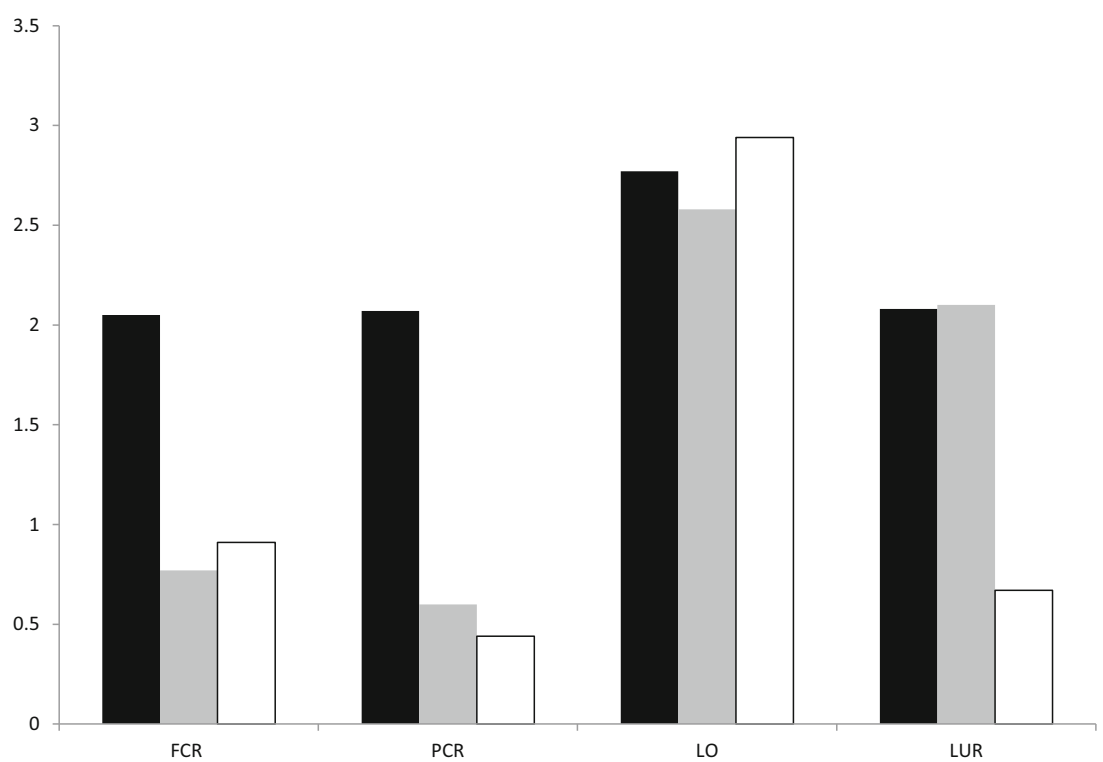

LUR insects or by by-products from the food or energy industry with a low economic value. Our dairy systems show a protein conversion ratios $<1.0$, clearly demonstrating the ability of ruminants to turn human-inedible feed ingredients into human-edible product. The protein conversion ratios of dairy cows on peat was lower (0.44) than of cows on sand $(0.60)$ because cows on peat consume relatively more grass. Grass has a relatively high protein content. Concentrates fed to dairy cows on peat, therefore, have a lower protein content than concentrates fed to cows on sand. In contrast to grass, some ingredients in concentrates are human-edible. The difference in protein conversion ratios between cows on peat and sand, therefore, is explained by the difference in protein content of concentrates fed to cows on peat and sand. Based on the protein conversion ratio results, we would conclude that dairy cows are more efficient than laying hens, whereas dairy cows on peat are most efficient.

Land use for production of $1 \mathrm{~kg}$ HDP from laying hens required slightly more compared to the production of $1 \mathrm{~kg}$ HDP from dairy cows on sandy soils but slightly less compared to the production of $1 \mathrm{~kg}$ HDP dairy cows on peat soils. Based on these Dutch case studies, therefore, we would not conclude that dairy production is more efficient than egg production. Moreover, production of milk on peat soils appears least efficient.

\subsection{Results from an 'energy' perspective}

Besides protein, ASF in many parts of the world also contributes to the energy demand of humans. For existing measures of land use efficiency, the main conclusions from the comparison among livestock systems presented in this study are valid also when presented from the 'energy' perspective, albeit slightly numerically modified (Table 8 ).
Using human-digestible energy instead of HDP in our computation of LUR, however, yielded different results: 6.39 for laying hens, 1.22 for dairy cows on peat soils, and 4.35 for dairy cows on sandy soils. These results demonstrate that none of our Dutch case systems produced human-digestible energy more efficiently than crops and support earlier findings that plants produce energy more efficiently than protein (Penning De Vries et al. 1974), whereas for livestock, this is reversed (Phuong et al. 2013). From the perspective of food supply, therefore, the main role of livestock in a human diet is provision of protein.

\section{General discussion}

The fact that livestock especially contribute to the protein demand of humans justifies our choice for HDP in the LUR. Protein digestibility was taken into account to correct for

Table 8 Energy conversion ratios (ECR), life cycle assessments of land occupation based on energy ( $\mathrm{LO}_{\mathrm{LCA} \text {,energy }}$ ) and our newly developed land use ratio based on energy (LUR energy ) for three case systems

\begin{tabular}{llll}
\hline Case systems & $\begin{array}{l}\text { ECR MJ GE HE } \\
\text { feed/MJ GE HE } \\
\text { product }^{\mathrm{b}}\end{array}$ & $\begin{array}{l}\mathrm{LO}_{\mathrm{LCA} \text {,energy }} \\
\mathrm{m}^{2} \text { year/MJ } \\
\mathrm{HDE}^{\mathrm{c}} \text { product }\end{array}$ & $\begin{array}{l}\mathrm{LUR}_{\text {energy }} \mathrm{MJ} \\
\mathrm{HDE} \text { in crop/MJ } \\
\mathrm{HDE} \text { in ASF }\end{array}$ \\
\hline $\begin{array}{l}\text { Laying hens } \\
\begin{array}{c}\text { Dairy cows on } \\
\text { peat }\end{array}\end{array}$ & 3.91 & 0.56 & 6.39 \\
$\begin{array}{c}\text { Dairy cows on } \\
\text { sand }\end{array}$ & 0.38 & 0.33 & 1.22 \\
\hline
\end{tabular}

${ }^{\text {a }} G E H E$ gross energy human-edible

${ }^{\mathrm{b}}$ product $=$ egg or milk

${ }^{\mathrm{c}} H D E$ human-digestible energy

${ }^{\mathrm{d}}$ ASF (animal-source food, including meat) 
differences in protein quality between plant and animal products, whereas differences in essential amino acid content between plants and animals were not accounted for. Besides protein, ASF has other nutritional qualities, such as the provision of iron and vitamin $B_{12}$. In principle, we could extend our LUR not only to consider human-digestible protein but also to include, for example, available iron, calcium, essential amino acids or vitamins. This, however, would require an index for nutritional quality of a food item. Such indices have been developed for individual food items and are referred to as nutrient density scores. These density scores relate the nutrient content of $100 \mathrm{~g}$ or $100 \mathrm{kcal}$ of a product to the daily recommended intake and average the values of different nutrients into one final score (Drewnowski and Fulgoni 2014). Despite a low nutrient density score, however, an individual food item can be valuable at the dietary level because of its richness in one very scarce nutrient. We believe, therefore, that the full range of nutritional needs should be met at the level of the entire human diet.

By applying the LUR method, it is possible to increase land use efficiency. However, to identify the contribution of livestock to future sustainable diets, one should also assess the contribution of livestock systems to global warming, acidification, eutrophication, water use, biodiversity and other environmental impacts. For example, a ruminant system on marginal grassland with a LUR $<1$ might have a relatively high global warming potential as feeding fibrous diets increases the production of enteric methane but could also contribute to the preservation and enhancement of biodiversity and the conservation of cultural landscapes when grasslands are managed well. We demonstrated the LUR for three case systems: laying hens, dairy cows on sandy soils and dairy cows on peat soils. These case systems represented existing livestock systems and were deliberately chosen because literature showed that they had comparable land use requirements from a life cycle perspective, while they differed in the percentage of humanedible feed in diets of animals and in opportunity costs of land for crop cultivation (sandy versus peat soils). Moreover, computation of LUR requires global, high-resolution inventory data, which were partly available for these existing systems. Despite the data availability, the LUR estimate of our case systems could have been refined further if the exact production location and associated yields of all purchased feed ingredients would have been known. Such detailed information about feed ingredients, however, is generally absent.

Our concept is applicable to a large variety of livestock systems and is of paramount importance in the debate about the role of livestock in global food supply. Several, especially LCA-based studies recommended to switch from an animalbased to a plant-based human diet, whereas others advice to substitute beef by pork or chicken to minimize land use in an animal-based diet (Stehfest et al. 2009; Meier and Christen 2012; Eshel et al. 2014). The above-mentioned studies, however, do not account for differences in the suitability of land to directly produce food crops. Our results clearly demonstrate that ruminant systems that value land with low opportunity costs for arable production can produce HDP more efficiently than crops and, therefore, do have a role in future food supply. In a situation of land scarcity, therefore, a plantbased diet is not more land efficient than a diet including animal-source food from, for example, ruminants grazing on land less suitable for crop production. Analogously, simply substituting beef by pork or chicken does not automatically imply improving efficiency of land use in terms of food supply. Beef and/or milk produced from grass on peat soils only would even result in a LUR of zero.

Our LUR enables identification of land-efficient livestock systems and allows further improvement of systems regarding efficiency of land use to contribute to future food supply. Land-efficient livestock systems (i.e. LUR $<1.0$ ) typically value land with low opportunity costs for arable production (e.g. beef or dairy cattle grazing 'marginal land') and/or byproducts from food or bio-energy production (e.g. pigs eating beet pulp or rapeseed meal). The amount of ASF that can be produced from 'marginal land' and by-products might not be sufficient to feed each human being a Western European or American diet. We acknowledge, therefore, that improving land use efficiency of livestock systems implies a more modest consumption of ASF in affluent countries. In countries where dietary diversity is limited and malnutrition levels are high, however, an increase in consumption of ASF is legitimate. A modest consumption of ASF is required also to temper environmental impacts of current and expected future demands of ASF. To use land efficiently, therefore, we should aim at increasing livestock productivity while maintaining a LUR $<1.0$.

\section{Conclusions}

Our results demonstrate that existing measures for efficiency of land use for livestock systems give insight into different aspects of the debate about the contribution of livestock to food supply and therefore food security. Conversion ratios are used to gain insight into the ability of animals to convert feed, or more specifically human-inedible feed, into animal products. Results show that improving the conversion of human-inedible feed into animal product improves land efficiency only if feed is produced on land with low opportunity costs for arable production (i.e. protein conversion ratios is lower for dairy cows than for laying hens, whereas LUR is similar for dairy cows on sandy soils and for laying hens). LCA results are used to gain insight into the land required to produce $1 \mathrm{~kg}$ ASF along the entire chain. Land use per kilogramme ASF reduces by increasing crop yield per hectare, reducing the feed conversion ratio and increasing 
the reproductive performance of animals. Land requirements per kilogramme ASF for cows on sand indeed are lower than for cows on peat, mainly because of the reduced FCR. This reduced FCR, however, also implied a diet with more human-edible plant products, i.e. the protein conversion ratios of cows on sand indeed was higher than of cows on peat. Improving LCA results of land use, therefore, might indirectly increase the amount of humanedible feed in diets of livestock and, as such, reduce the efficiency of land use in terms of food supply. None of the above-mentioned measures accounts for the opportunity costs of land to cultivate human food crops. Our LUR includes all aspects of importance to determine the role of livestock for future food supply, and, therefore, yields a more complete insight into land use efficiency for livestock systems. Results demonstrated that ruminant systems that value land with low opportunity costs for arable production can produce HDP more efficiently than crops and, therefore, do have a role in future food supply. Values $<1.0 \mathrm{dem}$ onstrate that livestock do contribute to food supply and therefore to food security. Our LUR offers identification of livestock production systems that use land efficiently in terms of food supply. Land-efficient livestock systems typically value land with low opportunity costs for arable production (e.g. peat soils or wet grasslands) and/or by-products from crop cultivation or the food or energy industry (e.g. beet pulp).

Acknowledgments We would like to thank Mark Dolman for providing necessary data for the dairy farming systems on sandy and peat soils and Theo Viets for his help related to using software. We wish to thank Mike Grossman for his help in formulating the title.

Open Access This article is distributed under the terms of the Creative Commons Attribution 4.0 International License (http:// creativecommons.org/licenses/by/4.0/), which permits unrestricted use, distribution, and reproduction in any medium, provided you give appropriate credit to the original author(s) and the source, provide a link to the Creative Commons license, and indicate if changes were made.

\section{References}

Borucke M, Moore D, Cranston G, Gracey K, Iha K, Larson J, Lazarus E, Morales JC, Wackernagel M, Galli A (2013) Accounting for demand and supply of the biosphere's regenerative capacity: the National Footprint Accounts' underlying methodology and framework. Ecol Indic 24:518-533

CVB (2012) Feed tables. (in Dutch: Tabellenboek veevoeding. CVBreeks nr. 50.) Productschap Diervoeder, Centraal Veevoederbureau, the Haque, the Netherlands

De Vries M, De Boer IJM (2010) Comparing environmental impacts for livestock products: a review of life cycle assessments. Livest Sci 128(1-3): 1-11

Dekker SEM, De Boer IJM, Vermeij I, Aarnink AJA, Groot Koerkamp PWG (2011) Ecological and economic evaluation of Dutch egg production systems. Livest Sci 13(1-2):109-121

Dijkstra J, France J, Ellis JL, Strathe AB, Kebreab E, Bannink A (2013) Productions efficiency of ruminants: feed, nitrogen and methane. In:
Kebreab E (ed) Sustainable animal agriculture. CAB International, Wallingford, pp 10-25

Drewnowski A, Fulgoni VL (2014) Nutrient density: principles and evaluation tools. Am J Clin Nutr 99(5):1223S-1228S

Eisler MC, Lee MRF, Tarlton JF, Martin GB, Beddington J, Dungait JAJ, Greathead H, Liu J, Mathew S, Miller H, Misselbrook T, Murray P, Vinod VK, Van Saun R, Winter M (2014) Steps to sustainable livestock. Nature 507:32-34

Eppendorfer WH, Eggum BO, Bille SW (1979) Nutritive value of potato crude protein as influenced by manuring and amino acid composition. J Sci Food Agric 30(4):361-368

Eshel G, Shepon A, Makov T, Milo R (2014) Land, irrigation water, greenhouse gas, and reactive nitrogen burdens of meat, eggs, and dairy production in the United States. Proc Natl Acad Sci 111(33): 11996-12001

FAO (2009) The state of food and agriculture. Livestock in balance. FAO, Rome

Farm Accountancy Data Network (2014) Subset of dairy farms derived from the Dutch Farm Accountancy Data Network for the years 2010-2012. LEI Wageningen UR, the Hague

Foley JA, Ramankutty N, Brauman KA, Cassidy ES, Gerber JS, Johnston M, Mueller ND, O'Connell C, Ray DK, West PC, Balzer C, Bennett EM, Carpenter SR, Hill J, Monfreda C, Polasky S, Rockstrom J, Sheehan J, Siebert S, Tilman D, Zaks DPM (2011) Solutions for a cultivated planet. Nature 478(7369):337-342

Gahlawat P, Sehgal S (1998) Protein and starch digestibilities and mineral availability of products developed from potato, soy and corn flour. Plant Foods Hum Nutr 52(2):151-160

Galloway JN, Burke M, Bradford GE, Naylor R, Falcon W, Chapagain AK, Gaskell JC, McCullough E, Mooney HA, Oleson KLL, Steinfeld H, Wassenaar T, Smil V (2007) International trade in meat: the tip of the pork chop. Ambio 36(8):622-629

Garnett T (2009) Livestock-related greenhouse gas emissions: impacts and options for policy makers. Environ Sci Technol 12(4):491-503

Gijsberts K (2013a) Linear programming cattle, pig, and poultry feedsreport no. 3, March 2013 (In Dutch: Lineaire programmering rundvee-, varkens en pluimveevoeders - Verslag nr. 3, maart 2013). Schothorst Feed Research, Lelystad, the Netherlands

Gijsberts K (2013b) Linear programming cattle, pig, and poultry feedsreport no. 6, June 2013 (In Dutch: Lineaire programmering rundvee-, varkens en pluimveevoeders - Verslag nr. 6, juni 2013). Schothorst Feed Research, Lelystad, the Netherlands

Gijsberts K (2013c) Linear programming cattle, pig, and poultry feedsreport no. 9, October 2013 (In Dutch: Lineaire programmering rundvee-, varkens en pluimveevoeders-Verslag nr. 9, oktober 2013). Schothorst Feed Research, Lelystad, the Netherlands

Gijsberts K (2013d) Linear programming cattle, pig, and poultry feedsreport no. 12, January 2013 (In Dutch: Lineaire programmering rundvee-, varkens en pluimveevoeders - Verslag nr. 12, januari 2013). Schothorst Feed Research, Lelystad, the Netherlands

Gilani GS, Cockell KA, Sepehr E (2005) Effects of antinutritional factors on protein digestibility and amino acid availability in foods. $\mathrm{J}$ AOAC Int 88(3):967-987

Godfray HCJ, Beddington JR, Crute IR, Haddad L, Lawrence D, Muir JF, Pretty J, Robinson S, Thomas SM, Toulmin C (2010) Food security: the challenge of feeding 9 billion people. Science 327(5967): $812-818$

Goodland R (1997) Environmental sustainability in agriculture: diet matters. Ecol Econ 23(3):189-200

Grassini P, Eskridge KM, Cassman KG (2013) Distinguishing between yield advances and yield plateaus in historical crop production trends. Nat Commun 4, art. no. 2918

Guinée JB, Gorrée M, Heijungs R, Huppes G, Kleijn R, De Koning A, Van Oers L, Wegener Sleeswijk A, Suh S, de Haes HA U, De Bruijn H, Van Duin R, Huijbregts MAJ (2002) Handbook on life cycle 
assessment. Operational guide to the ISO standards. Kluwer Academic Publishers, Dordrecht

IIASA, FAO (2012) Global Agro-ecological Zones (GAEZ v3.0). IIASA, Laxenburg, Austria and FAO, Rome, Italy

Khan MA, Saeeda J, Rana IA, Ihsan U (1992) Improvement of wheat protein by supplementation with potato flour. Pak J Agric Res 13(2): 101-106

Kies C, Fox HM (1972) Effect of amino acid supplementation of dehydrated potato flakes on protein nutritive value for human adults. J Food Sci 37(3):378-380

KWIN-AGV (2012) Quantitative information arable farming and open-air horticulture 2012 (In Dutch: Kwantitatieve Informatie Akkerbouw en Vollegrondsgroenteteelt 2012). Wageningen UR Praktijkonderzoek Plant en Omgeving, Lelystad, the Netherlands

KWIN-V (2013) Quantitative information livestock 2013-2014 (In Dutch: Kwantitatieve Informatie Veehouderij 2013-2014). Wageningen UR Livestock Research, Lelystad, the Netherlands

Meier T, Christen O (2012) Environmental impacts of dietary recommendations and dietary styles: Germany as an example. Environ Sci Technol 47(2):877-888

Neeteson-van Nieuwenhoven A-M, Knap P, Avendaño S (2013) The role of sustainable commercial pig and poultry breeding for food security. Anim Front 3(1):52-57

Penning De Vries FWT, Brunsting AHM, Van Laar HH (1974) Products, requirements and efficiency of biosynthesis a quantitative approach. J Theor Biol 45(2):339-377

Phuong HN, Friggens NC, de Boer IJM, Schmidely P (2013) Factors affecting energy and nitrogen efficiency of dairy cows: a meta-analysis. J Dairy Sci 96(11):7245-7259
Ravindran V, Ravindran G, Sivakanesan R, Rajaguru SB (1995) Biochemical and nutritional assessment of tubers from 16 cultivars of sweet potato (Ipomoea batatas L.). J Agric Food Chem 43(10):2646-2651

Ridoutt BG, Page G, Opie K, Huang J, Bellotti W (2012) Assessing carbon, water and land use footprints for beef cattle production in southern Australia. In: Corson MS, Van der Werf HMG (eds) 8th International conference on life cycle assessment in the Agri-Food Sector (LCA Food 2012), 1-4 October 2012, Saint Malo, France, 14 October 2012. INRA, Rennes, pp 599-604

RIVM (2013) Agricultural practice and water quality at grassland farms under derogation - results for 2011 within the framework of the derogation monitoring network (in Dutch: Landbouwpraktijk en waterkwaliteit op landbouwbedrijven aangemeld voor derogatieResultaten meetjaar 2011 in het derogatiemeetnet). Vol RIVM Rapport 680717034. Bilthoven, the Netherlands

Stehfest E, Bouwman L, van Vuuren DP, den Elzen MGJ, Eickhout B, Kabat P (2009) Climate benefits of changing diet. Clim Chang 95(1-2):83-102

Tilman D, Balzer C, Hill J, Befort BL (2011) Global food demand and the sustainable intensification of agriculture. Proc Natl Acad Sci U S A 108(50):20260-20264

USDA (2013) Composition of foods raw, processed, prepared USDA national nutrient database for standard reference, release 26-documentation and user guide. U.S. Department of AgricultureAgricultural Research Service, Beltsville

Vellinga TV, Blonk H, Marinussen M, Van Zeist WJ, De Boer IJM (2013) Methodology used in feedprint: a tool quantifying greenhouse gas emissions of feed production and utilization. Wageningen UR, Lelystad

Wilkinson JM (2011) Re-defining efficiency of feed use by livestock. Animal 5(07):1014-1022 